\title{
ARLOKA MAP: MEDIA PENGENALAN NILAI-NILAI KEARIFAN LOKAL DI KAWASAN CANDI PRAMBANAN
}

\section{ARLOKA MAP: A MEDIA INTRODUCES VALUES OF LOCAL WISDOM OWNED BY THE PRAMBANAN TEMPLE AREA}

\author{
Sandy Maulana Yusuf ${ }^{*}$, Indah Nurafani Syarqiyah², Naufal Raffi Arrazaq ${ }^{3}$ \\ Mahasiswa Departemen Arkeologi, Fakultas Ilmu Budaya, \\ Universitas Gadjah Mada, Indonesia ${ }^{1,2,3}$ \\ sandymaulanay@gmail.com
}

\begin{abstract}
Prambanan Temple contains local wisdom values that have not been well informed to domestic visitors. This article aims to introduce Arloka Map, an alternative communication media in a form of physical tour-map containing local wisdom values of the Prambanan Temple Area and to test the effectiveness rate of the Arloka-Map. Observation, literature studies, and instrument test methods were used to collect basic data. To determine the success rate of the proposed strategy, pre- and post-tests were conducted to 50 domestic tourist respondents. The outcomes were then analyzed by using the SPSS application. Results showed that score for visitors that were using the ArlokaMap was higher than visitors who did not use it (i.e. 8.72 vs 4.44). It was concluded that the use of the Arloka-Map assist tourists to know the values of local wisdoms at the temple's area.
\end{abstract}

Keywords: Prambanan temple area; local wisdom; domestic tourist; Arloka Map

\section{ABSTRAK}

Wisatawan domestik di Candi Prambanan cenderung tidak mempedulikan nilai kearifan lokal. Masalah ini berusaha dipecahkan melalui uji coba pengunaan Arloka Map. Arloka Map adalah media komunikasi alternatif berbentuk peta wisata fisik, yang di dalamnya memuat nilai kearifan lokal Kawasan Candi Prambanan. Penelitian ini bertujuan menguji tingkat efektivitas Arloka Map dalam membantu wisatawan domestik mengenali nilai kearifan lokal. Observasi, studi pustaka, dan pembagian soal uji digunakan untuk mengumpulkan data. Untuk mengukur tingkat keberhasilan strategi yang diajukan, penulis menggunakan pre-test dan post-test yang dianalisis menggunakan aplikasi Statistical Package for The Social Sciences. Berdasarkan hasil analisis yang dilakukan terhadap lima puluh wisatawan domestik, diperoleh rerata nilai pre-test 4,44 (pra penggunaan Arloka Map) dan rerata nilai post-test 8,72 (pasca penggunaan Arloka Map). Dapat disimpulkan bahwa penggunaan Arloka Map membantu wisatawan mengenali nilai kearifan lokal Candi Prambanan.

Kata Kunci: Kawasan Candi Prambanan; nilai kearifan lokal; wisatawan domestik; Arloka Map

Artikel Masuk 


\section{PENDAHULUAN}

Kawasan Candi Prambanan ${ }^{1}$ adalah salah satu mahakarya arsitektur Indonesia yang telah diakui keindahannya oleh dunia. Sejak tahun 1991, United Nations Educational, Scientific, and Cultural Organization (UNESCO), badan khusus Perserikatan Bangsa-Bangsa (PBB) yang bergerak di bidang pendidikan, ilmu pengetahuan, dan budaya, telah menetapkan kompleks Candi Prambanan dan Candi Sewu sebagai warisan dunia dengan nomor C-642. Dalam deskripsi yang ditulis di situs resmi Kementerian Pendidikan dan Kebudayaan (Kemdikbud) Republik Indonesia, UNESCO menjelaskan bahwa kedua candi ini telah memenuhi kriteria sebagai representasi mahakarya kreativitas dan kecerdasan manusia yang berasal dari abad ke-10 Masehi. Kedua candi juga dapat menjadi contoh karya arsitektural, harmonisasi teknologi, dan lanskap budaya yang mampu menggambarkan tahapan perkembangan penting dalam sejarah kehidupan manusia.

Kawasan Candi Prambanan telah ditetapkan sebagai Kawasan Cagar Budaya dengan peringkat nasional melalui Surat Keputusan Menteri Pendidikan dan Kebudayaan No. 278/M/2014 dan Surat Keputusan Menteri Pendidikan dan Kebudayaan No. 157/M/1998. Berdasarkan definisi cagar budaya dalam Undang-Undang Republik Indonesia Nomor 11 Tahun 2010 tentang Cagar Budaya, Kawasan Candi Prambanan perlu dilestarikan keberadaannya karena memiliki nilai penting dengan taraf nasional bagi sejarah, ilmu pengetahuan, pendidikan, agama, dan/atau kebudayaan bangsa. Kawasan Candi Prambanan adalah mahakarya yang dianggap penting oleh masyarakat Indonesia.

Nilai penting Kawasan Candi Prambanan sangat beragam, salah satunya berupa nilai-nilai kearifan lokal. Nilai kearifan lokal adalah ekspresi kepribadian, identitas, pandangan, dan sistem hidup masyarakat tertentu yang terkandung dalam kekayaan budaya lokal, baik yang berbentuk tangible maupun intangible (Sedyawati, 2006, hlm. 183). Nilai kearifan lokal juga dapat dipahami sebagai kepribadian budaya bangsa yang mampu bertahan, mengakomodasi, dan menginterogasi unsur-unsur budaya luar ke dalam kebudayaan sendiri (Muhardjito dalam Lestari, 2000, hlm. 31)

Candi-candi yang terdapat di Indonesia, termasuk Kawasan Candi Prambanan, berbeda dengan kuil di India. Perbedaan tersebut dapat dipahami sebagai akibat adanya kearifan lokal yang dimiliki nenek moyang Nusantara. Berdasarkan hasil penelitian mengenai arsitektur candi yang dilakukan oleh Jai Singh Yadav, peneliti yang mendalami relasi budaya antara Indonesia dan India, terdapat indikasi upaya penggabungan unsur-unsur India ke dalam arsitektural candi-candi di Nusantara (Yadav, 2002, hlm. 11).

Perpaduan antara unsur budaya lokal dengan unsur budaya asing hanya dapat terjadi apabila masyarakat Nusantara memegang teguh nilai-nilai kearifan lokal yang diwariskan nenek moyang. Hasilnya, candi-candi yang ada di Indonesia memiliki ragam hias relief dan teknik konstruksi yang berbeda dengan kuil di India. Hal ini menjadi penanda bahwa para leluhur Nusantara memiliki kemampuan untuk memfilter budaya asing yang mereka terima dengan kecerdasan lokal yang telah dipahami sebelumnya.

${ }^{1}$ Mencakup Candi Prambanan, Candi Sewu, dan Candi Plaosan. 
Pada Kawasan Candi Prambanan, sedikitnya terdapat tiga kelompok nilai kearifan lokal yang dapat ditemui, yaitu aspek seni relief, aspek teknik konstruksi, dan aspek keletakan candi. Akan tetapi, nilai-nilai kearifan lokal yang telah disebutkan di atas, tampaknya tidak disadari oleh masyarakat luas dan hanya berkembang di kalangan para akademisi saja. Padahal, kawasan candi ini dikunjungi jutaan wisatawan per tahun.

Data terbaru yang dirilis Badan Pusat Statistik (BPS) Kabupaten Sleman menyebut, selama tahun 2018, Candi Prambanan dikunjungi 1.998.437 wisatawan. Berdasarkan data yang dirilis BPS Kabupaten Klaten, selama tahun 20172, Candi Sewu dan Candi Plaosan dikunjungi 13.941 wisatawan. Jika angka-angka itu dijumlahkan secara kasar, maka total kunjungan ke Candi Prambanan, Candi Sewu, dan Candi Plaosan mencapai dua juta wisatawan per tahun. Jumlah tersebut tergolong sangat banyak bagi ukuran destinasi pariwisata. Namun, kecenderungan wisatawan domestik yang kurang peduli dengan nilai kearifan lokal Kawasan Candi Prambanan, menjadi masalah tersendiri yang harus diatasi.

Menurut Fauzan Amril3, lemahnya pengetahuan dan pemahaman masyarakat terhadap cagar budaya, dalam kasus ini pemahaman wisatawan domestik terhadap Kawasan Candi Prambanan, dapat berdampak buruk terhadap kelestarian cagar budaya tersebut (Amril, 2016, hlm. 3-4). Raharjana, dkk., (2016, hlm. 3-23) berpendapat bahwa kurangnya pemahaman wisatawan domestik terhadap arti penting Kawasan Candi Prambanan sangat mungkin terjadi karena masyarakat tidak memperoleh manfaat secara langsung dari keberadaan cagar budaya. Hal ini dikhawatirkan dapat mengakibatkan munculnya perilaku yang tidak diinginkan, seperti halnya vandalisme, atau berfoto dengan pose-pose berlebihan (melompat beramai-ramai atau menaiki pagar langkan), yang dapat merusak candi.

Wisatawan cenderung memandang candi hanya sebagai daya tarik wisata foto yang estetik. Tidak lebih dari itu. Penelitian mengenai latar belakang kunjungan wisatawan ke Candi Prambanan yang dilakukan Tita Siti Yusnitha di tahun 2017 mendukung pernyataan tersebut. Penelitian ini menggunakan 75 responden. Cakupan penelitian Yusnitha terbatas pada Candi Prambanan.

Berdasarkan hasil penelitian Yusnitha, 76\% wisatawan domestik yang berkunjung ke Candi Prambanan datang agar dapat berfoto di latar bangunan candi yang megah (Yusnitha, 2017, hlm. 10). Bukan sesuatu yang salah memang, tetapi secara tidak langsung, hal ini mendevaluasi status Kawasan Candi Prambanan menjadi sebatas objek wisata saja.

Kawasan Candi Prambanan merupakan kawasan cagar budaya yang dijadikan daya tarik wisata. Wisatawan diharapkan datang dengan niat menikmati, mengeksplorasi, dan mempelajari nilai kearifan lokal yang melekat di Kawasan Candi Prambanan. Kondisi ideal seperti ini yang seharusnya terjadi menurut perspektif arkeologis. Faktanya, kondisi ideal yang diharapkan arkeologi, sering kali tidak sejalan dengan kenyataan di lapangan. Masih banyak wisatawan domestik yang berkunjung ke Kawasan Candi Prambanan tanpa memedulikan status kawasan ini sebagai cagar budaya.

2 Data termutakhir yang dimiliki BPS Kabupaten Klaten

${ }^{3}$ Fauzan Amril adalah lulusan program Magister Arkeologi, Universitas Indonesia, yang kini bekerja di Balai Pelestarian Cagar Budaya Sumatra Barat 
Kegagalan wisatawan domestik (sebagai bagian dari masyarakat) memahami nilai kearifan lokal cagar budaya merupakan salah satu faktor pendorong lahirnya diskursus "Arkeologi Publik". Perbedaan antara ranah arkeologi dan masyarakat telah menjadi pokok permasalahan penting sejak 1939. Grahame Clark dalam bukunya Archaeology and Society bertanya: apakah arkeologi layak mendapatkan dana penelitian dari masyarakat apabila tidak menghasilkan sesuatu yang berguna? Clark merasa, arkeologi baru layak menerima itu semua apabila mampu memuaskan kebutuhan masyarakat. Kebutuhan tersebut berupa pengetahuan yang selalu mereka dambakan, yaitu asal-usul dan perjalanan sejarah manusia (Tanudirjo, 2013, hlm. 4).

Ketika Charles McGimsey mulai menyebut istilah "Arkeologi Publik" pada 1972, Arkeologi Publik seakan terbatas pada Arkeologi Konservasi dan Cultural Resources Management. Dewasa ini, pemahaman mengenai Arkeologi Publik semakin meluas (Matsuda, 2004, hlm. 66). Kajian Arkeologi Publik masa kini mulai melibatkan peran masyarakat. Peran tersebut dapat dilihat dari kemampuan masyarakat mengenali nilai kearifan lokal yang melekat di cagar budaya.

Upaya mengenalkan nilai kearifan lokal Kawasan Candi Prambanan kepada wisatawan domestik dapat dilakukan dengan berbagai cara. Artikel ini berusaha memperkenalkan Arloka Map sebagai salah satu medium yang dapat digunakan untuk mencapai tujuan tersebut.

Arloka Map adalah peta wisata berbentuk fisik kreasi penulis, yang di dalamnya memuat informasi kearifan lokal candi di Kawasan Prambanan. Mulai dari teknik konstruksi hingga seni hias dan relief candi. Sasaran utama dari Arloka Map adalah wisatawan domestik yang secara umum kurang dapat mengenali nilai-nilai kearifan lokal yang terdapat di Kawasan Candi Prambanan. Agar mudah dipahami, informasi muatan nilai-nilai kearifan lokal tersebut dikemas menggunakan bahasa populer. Wisatawan dapat membaca materi tersebut dengan memindai kode Quick Response (QR) yang terdapat pada peta. Wisatawan kemudian diminta menjelajah candi dengan Arloka Map untuk menemukan secara mandiri nilai kearifan lokal Kawasan Candi Prambanan.

Penulisan risalah ini berfokus pada dua tujuan. Pertama, memperkenalkan penggunaan Arloka Map sebagai media komunikasi alternatif berbentuk peta wisata fisik, yang di dalamnya memuat nilai-nilai kearifan lokal Kawasan Candi Prambanan. Kedua, menguji tingkat efektivitas Arloka Map dalam membantu wisatawan domestik mengenali nilai kearifan lokal yang ada.

\section{METODE}

Kecenderungan wisatawan domestik untuk tidak memedulikan dan kurang memahami nilai-nilai kearifan lokal adalah masalah yang kini dihadapi Kawasan Candi Prambanan. Permasalahan tersebut berusaha dipecahkan artikel ini melalui pengenalan dan uji coba penggunaan Arloka Map. 
Penelitian ini menggunakan metode kuantitatif yang dibangun berdasarkan pendekatan Arkeologi Publik. Menurut Hadari Nawawi ${ }^{4}$ (2003, hlm. 32), metode kuantitatif adalah suatu cara yang digunakan untuk menjawab masalah penelitian dengan menyimbolkan variabel penelitian dalam bentuk angka untuk memudahkan proses analisis data. Pendekatan Arkeologi Publik adalah salah satu bagian dalam disiplin arkeologi yang memfokuskan kajiannya untuk mempelajari dan mengkritik proses produksi dan konsumsi komoditas arkeologi (Grima, 2009, hlm. 53). Arkeologi Publik berfokus pada kajian cara arkeologi berinteraksi dengan masyarakat luas (Matsuda, 2004, hlm. 68).

Tahap penelitian ini terdiri atas pengumpulan data. Lalu, pembuatan media Arloka Map. Kemudian, tahap implementasi Arloka Map (uji efektivitas terhadap wisatawan domestik). Terakhir, analisis hasil implementasi.

Pengumpulan data dilakukan melalui observasi lapangan. Data yang diobservasi meliputi kenampakan relief, teknik konstruksi, dan keletakan candi di Kawasan Prambanan. Candi-candi yang menjadi objek observasi antara lain Candi Prambanan, Candi Sewu, dan Candi Plaosan. Melalui pengamatan relief candi, teknik konstruksi, dan keletakan candi, data yang memuat kearifan lokal lalu didokumentasikan menggunakan kamera digital.

Tahap kedua adalah pembuatan Arloka Map. Sebagaimana yang telah dijelaskan di bagian pendahuluan, Arloka Map adalah media penyampaian informasi kearifan lokal di Kawasan Candi Prambanan yang disarikan, kemudian dicetak dalam bentuk fisik. Penyusunan konten dalam Arloka Map memerlukan poin-poin kearifan lokal yang disarikan dari data pustaka dan data observasi lapangan. Poin-poin tersebut kemudian dinarasikan dengan bahasa populer dan diolah menggunakan aplikasi Microsoft Powerpoint dan Adobe Photoshop. Dokumen materi yang sebelumnya memiliki ekstensi .pdf, lalu diunggah ke layanan cloud server. Dokumen ini kemudian diubah ke dalam bentuk kode QR sehingga materi dapat diakses oleh wisatawan dengan cara memindai kode tersebut. Pembuatan Arloka Map-konfigurasi peta, legenda, dan peletakan kode QR pada tubuh petadilakukan dengan aplikasi QGIS.

Tahapan implementasi media Arloka Map dilakukan terhadap wisatawan domestik di Candi Prambanan, Candi Sewu, dan Candi Plaosan. Responden dipilih secara acak dari latar belakang usia yang berbeda. Tujuan dari pemilihan usia yang berbeda adalah mengetahui tingkat efektivitas media Arloka Map. Setelah mendapatkan Arloka Map, responden diberi kesempatan untuk mengelilingi candi yang mereka kunjungi. Sebelum berkeliling, responden diberikan soal pre-test. Tujuannya adalah mengukur tingkat pemahaman responden sebelum menggunakan media Arloka Map. Post-test diberikan setelah responden menggunakan media Arloka Map untuk mengevaluasi tingkat pemahaman responden terhadap nilai-nilai kearifan lokal yang dikunjungi.

Hasil pre-test dan post-test dianalisis menggunakan aplikasi Statistical Package for the Social Sciences (SPSS). Analisis dilakukan untuk mengetahui nilai yang diperoleh setiap responden, nilai rata-rata keseluruhan responden, dan jumlah skor benar atau salah dari setiap pertanyaan. Hal tersebut bertujuan untuk

${ }^{4}$ Guru Besar Fakultas Keguruan dan Ilmu Pendidikan, Universitas Tanjungpura yang ahli di bidang metodologi penelitian. 
mengetahui tingkat efektivitas Arloka Map sebagai salah satu upaya mengenalkan nilai kearifan lokal yang melekat pada Kawasan Candi Prambanan.

Hal terpenting yang harus diingat, pada dasarnya, Arloka Map merupakan prototipe media yang bersifat baru dan masih dalam tahap uji coba. Arloka Map yang masih berbentuk digital dapat diunduh melalui laman: ugm.id/arlokamap. Meskipun pada tahap implementasi, Arloka Map telah dibagikan kepada lima puluh responden. Namun, hal ini hanya dimaksudkan untuk mengetahui efektivitas Arloka Map dalam membantu wisatawan domestik mengenali nilai kearifan lokal yang ada. Dengan kata lain, berbagai macam pengembangan dan uji coba lanjutan tetap diperlukan untuk menyempurnakan media ini.

\section{HASIL PENELITIAN}

\section{Jelajah Dengan Arloka Map}

Fenomena wisatawan domestik yang berkunjung ke Kawasan Candi Prambanan hanya demi foto estetik merupakan hal yang umum terjadi. Pada dasarnya, orang berwisata untuk merasa senang dan melepaskan diri dari rutinitas hidup yang membosankan (Sagala, 2017, hlm. 2-3). Beberapa peneliti seperti Haldrup \& Larsen (2003, hlm. 23-46) dan Gillet, dkk. (2013, hlm. 37-57) menemukan keterkaitan antara perilaku berfoto wisatawan dengan kebahagiaan selama melakukan aktivitas wisata (Hastuti, 2017, hlm. 540-554). Berdasarkan hal tersebut, menunjukkan tujuan utama berwisata adalah bahagia. Apabila arkeolog ingin memperkenalkan nilai kearifan lokal kepada wisatawan domestik, adalah menyampaikan nilai tersebut dengan cara yang menyenangkan.

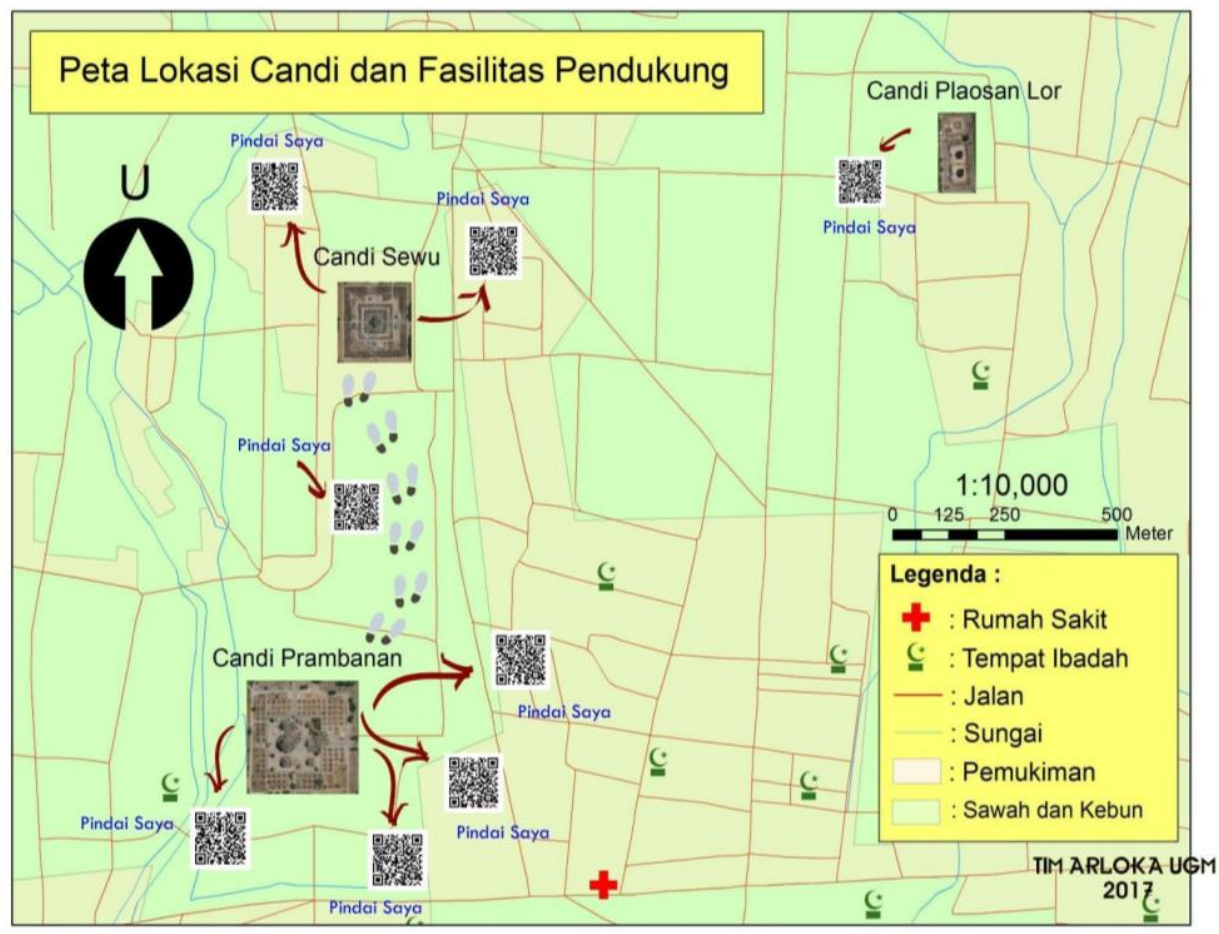

Gambar 1: Arloka Map, Peta Kearifan Lokal Kawasan Candi Prambanan (Sumber: Tim Arloka) 
Berangkat dari hal tersebut, Arloka Map menawarkan konsep jelajah candi. Jelajah tersebut memungkinkan wisatawan domestik mengenali, menemukan, dan memahami secara mandiri nilai kearifan lokal yang melekat di Kawasan Candi Prambanan (Gambar 1). Arloka Map memuat delapan nilai kearifan lokal Kawasan Candi Prambanan, yang secara umum dapat dibagi ke dalam tiga kelompok. Terdiri atas aspek seni relief, aspek teknik konstruksi, dan aspek keletakan candi.

\section{Aspek Seni Relief pada Kawasan Candi Prambanan}

Relief adalah gambar dalam bentuk ukiran yang dipahat. Relief yang dipahatkan pada candi biasanya mengandung arti atau menggambarkan peristiwa tertentu (Ayatrohaedi, 1979, hlm. 149). Seringkali, selain memuat adegan epos dari cerita-cerita gubahan para pujangga, atau dari kitab agama Hindu dan Buddha, relief candi juga dapat menguraikan kehidupan masyarakat pada masa tersebut. Hal ini disebabkan, ketika para seniman Indonesia memahat relief, mereka juga mencampurkan unsur-unsur Indonesia, dan aturan-aturan lainnya sesuai dengan kondisi lokal (Yadav, 2002, hlm. 12).

Seniman memahat relief berdasarkan pengalaman dan pengamatannya pada kehidupan sekitar. Relief candi adalah salah satu bentuk dokumentasi terbaik mengenai kehidupan manusia pada masa candi tersebut dibangun. Pada relief Candi Prambanan ditemukan banyak panel yang dapat memberikan gambaran mengenai kehidupan masyarakat Mataram Kuno. Panel-panel pada relief Candi Prambanan juga memuat nilai-nilai kearifan lokal yang dapat diketahui dengan bantuan Arloka Map. Berikut beberapa di antaranya:

\section{Cerita pertanian Nusantara dari relief Candi Prambanan}

Sejak orang Austronesia membawa kebudayaan bercocok tanam ke Nusantara ketika masa prasejarah, berbagai alat terus dikembangkan demi memenuhi kebutuhan pertanian. Untuk membantu mengolah padi, leluhur Nusantara menciptakan alat berupa alu dan lumpang. Alu sendiri adalah alat berbentuk seperti tabung memanjang yang biasanya terbuat dari kayu dan digunakan untuk menumbuk gabah agar terpisah dari sekamnya. Lumpang adalah wadah yang digunakan untuk meletakkan gabah saat ditumbuk.

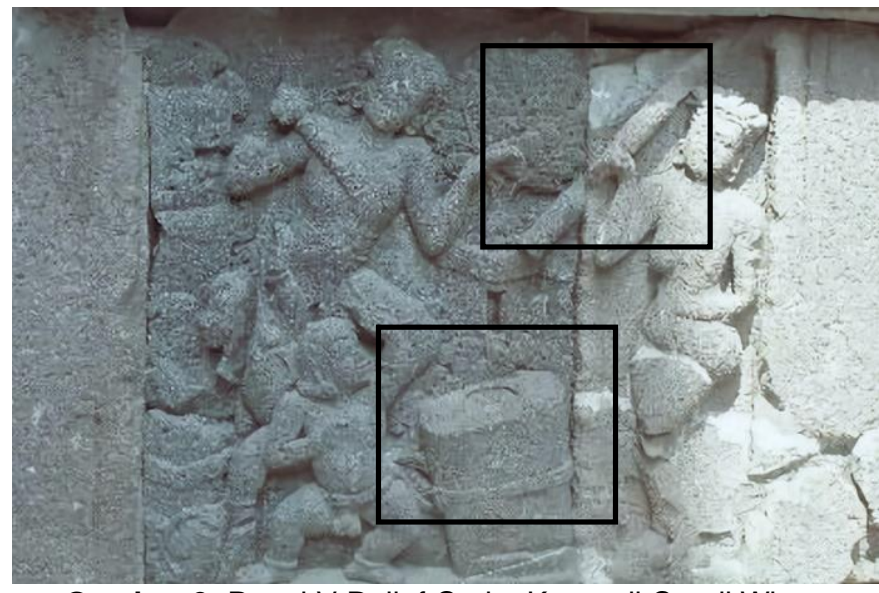

Gambar 2: Panel V Relief Cerita Krsna di Candi Wisnu (Sumber: Tim Arloka) 
Pentingnya peran alu dan lumpang dalam kehidupan masyarakat Jawa masa Kerajaan Mataram Kuno membuat kedua alat tersebut turut digambarkan di relief-relief Candi Prambanan. Wisatawan domestik yang tengah menjelajah Candi Prambanan dengan Arloka Map dapat menemukan alu dan lumpang pada panel V relief cerita Krsna di Candi Wisnu.

Panel ini menggambarkan adegan seorang anak kecil yang tengah diikat di sebuah lumpang batu. Di belakangnya, berdiri dua wanita yang tengah membawa alu. Andri Restiyadi ${ }^{5}$ yang melakukan penelitian mengenai analisis seni relief Candi Prambanan di tahun 2006, menginterpretasi panel relief tersebut sebagai adegan Krsna kecil yang tengah dihukum akibat menumpahkan susu perahan (Restiyadi, 2006, hlm. 63). Keberlanjutan penggunaan alu dan lumpang oleh leluhur Nusantara sejak masa prasejarah hingga awal kemerdekaan, dapat menjadi bukti bahwa kedua alat tersebut merupakan identitas budaya pertanian Indonesia yang patut dilestarikan (Gambar 3).

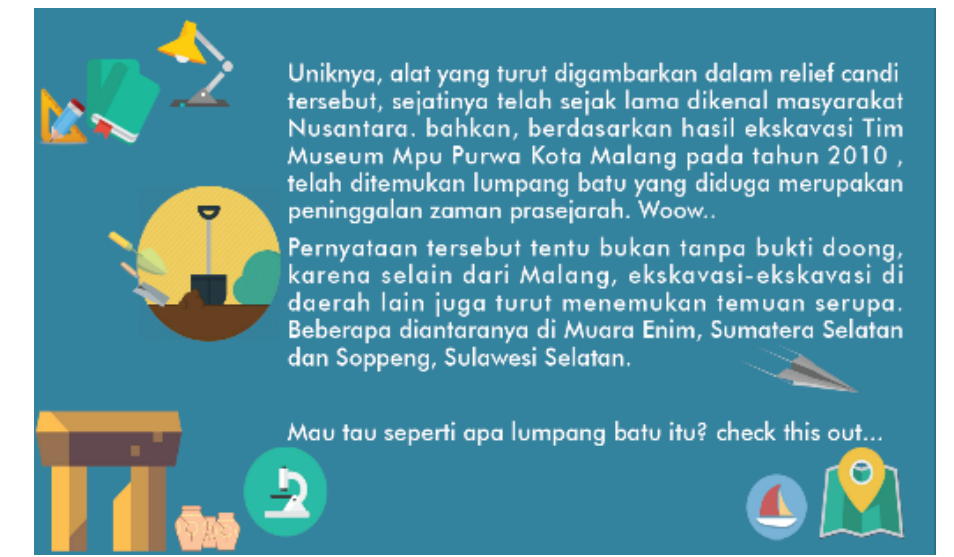

Gambar 3: Contoh Artikel Populer yang Dapat Diakses di Arloka Map

(Sumber: Tim Arloka)

\section{Pertunjukan seni tari di relief Candi Prambanan}

Terdapat kurang lebih 62 panel relief yang menggambarkan kesenian tari di pagar langkan Candi Prambanan (Siagian, 2002, hlm. 94). Banyaknya jumlah panel yang menampakkan sosok penari di relief Candi Prambanan membuat Edi Sedyawati tertarik melakukan penelitian dengan topik tersebut. Hasilnya, Sedyawati menemukan kesamaan antara beberapa sikap tari yang ditampilkan dalam panel relief dengan sikap yang terdapat dalam buku Natyasastra India seperti agratalasancara, ancita, sama, dan udghattita (Sedyawati, 1994, hlm. 170).

Pada perkembangan selanjutnya, leluhur Nusantara hanya mengambil konsep posisi dan gerak jari dari seni tari India. Selebihnya, kekhasan gaya tari Nusantara seperti kedekatan dengan tanah, tetap dipertahankan. Terdapat banyak frase tari Nusantara yang memiliki gerak cenderung mengarah ke tanah, seperti, membungkuk, duduk, atau menekuk lutut (Holt, 2000, hlm. 116). Relief seni musik dan tari di Candi Prambanan dapat menjelaskan kecerdasan leluhur Nusantara dalam mengolah budaya asing agar sesuai dengan budaya Nusantara.

\footnotetext{
${ }^{5}$ Sekarang menjadi penelti di Balai Arkeologi Sumatra Utara
} 


\section{Bentuk bangunan masa Mataram Kuno di relief Candi Prambanan}

Dalam perjalanannya mengelilingi Candi Prambanan bersama Arloka Map, wisatawan akan mengetahui bila masyarakat masa Mataram Kuno sudah mempertimbangkan kondisi alam ketika membangun hunian. Panel II dari relief Krsna menggambarkan bentuk bangunan beratap limasan yang dibuat dengan genteng sirap (Gambar 4). Penggunaan bentuk atap limasan membantu tetes-tetes hujan yang mengguyur atap untuk cepat jatuh ke tanah. Pemilihan genteng sirap sebagai komponen penyusun atap membantu suhu dan kelembapan rumah tetap terjaga berkat kemampuannya menyerap panas berlebih.

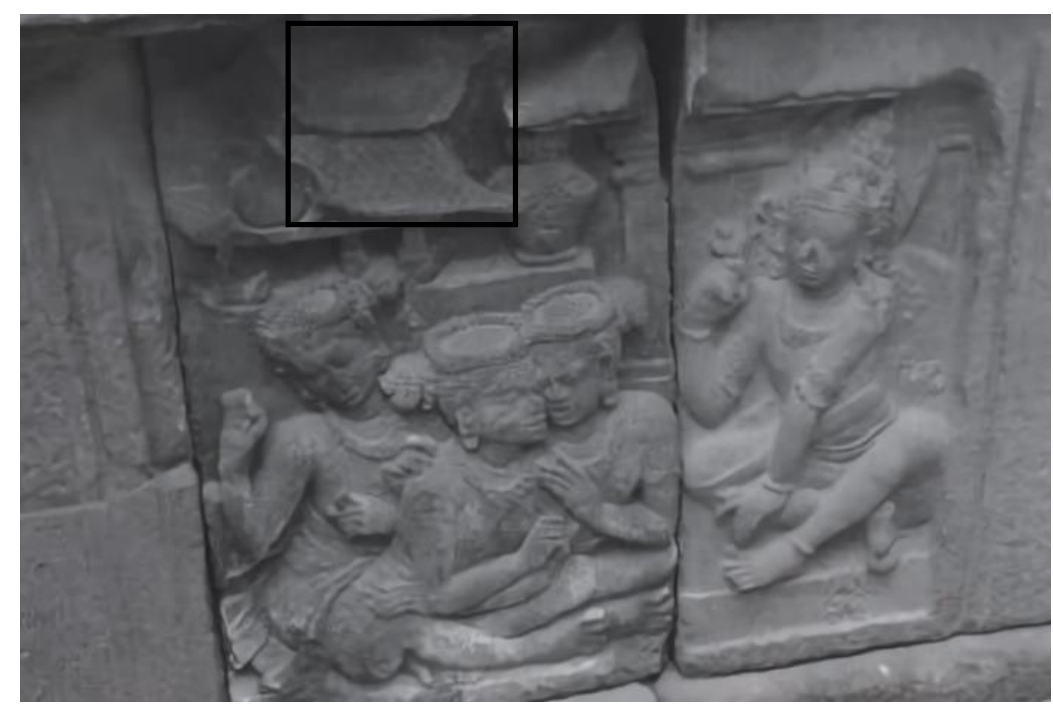

Gambar 4: Panel II Relief Cerita Krsna di Candi Wisnu

(Sumber: Tim Arloka)

Panel XXII dan XXIV dari relief Krsna turut menunjukkan bentuk bangunan yang berkolong. Kolong ini dapat digunakan sebagai tempat menyimpan hasil pertanian. Rumah masa Mataram Kuno juga dibangun dengan letak lantai yang cukup tinggi dari permukaan tanah (Gambar 5). Hal ini bertujuan untuk menghindari serangan binatang buas. Relief bangunan di Candi Prambanan dapat menjelaskan kecerdasan leluhur Nusantara dalam mengadaptasi sumber daya alam yang tersedia untuk memenuhi kebutuhan mereka akan bangunan.

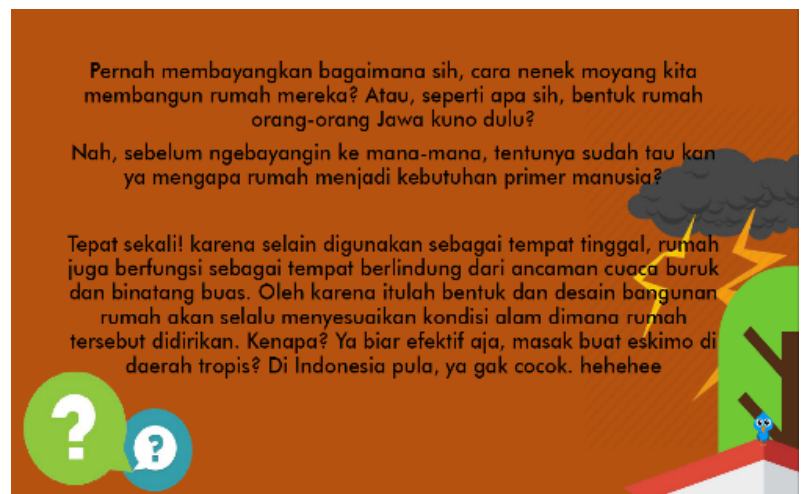

Gambar 5: Penjelasan Arloka Map mengenai Pengaruh Iklim terhadap Bentuk Bangunan Masa Mataram Kuno

(Sumber: Tim Arloka) 


\section{Kala Candi Sewu dan tradisi topeng Nusantara}

Sejak lama, topeng memiliki peran yang penting dalam kebudayaan Nusantara. Topeng digunakan sebagai alat mediasi antara dunia manusia dengan dunia roh. (Wibowo, dkk., 2006, hlm. 1-4). Masyarakat Jawa Kuno juga mengenal tradisi pembuatan topeng. Hal ini dapat diketahui dari adanya istilah matapukan dan manapel dalam prasasti Waharakuti (840 Masehi) dan Mantyasih (904 Masehi), yang keduanya berarti menari topeng (Soedarsono dalam Wibowo, 2006, hlm. 6-9). Kedua istilah itu mengindikasikan pergeseran fungsi topeng dari media perantara alam manusia dan roh, menjadi media kesenian.

Pada mulanya, topeng digambarkan dalam wujud dewa, hewan-hewan mitologi yang menyeramkan, hingga hewan yang lebih rendah dari manusia. Dalam perkembangan selanjutnya, topeng memiliki karakter yang lebih variatif, untuk menunjukkan suatu tokoh atau sifat tertentu (Wibowo, 2006, hlm. 10-14). Apabila diperhatikan, penggambaran kala sebagai perwujudan makhluk mitologi yang terdapat pada bangunan candi, memiliki bentuk yang berbeda dengan kala (dikenal juga dengan istilah kirttimukha) yang terdapat pada kuil di India (Gambar 6). Istilah kala adalah penyebutan yang khas di Indonesia. Di Jawa, kala digambarkan sebagai kepala raksasa berwajah keras, sedangkan di India, kala (kirttimukha) digambarkan sebagai hewan bertanduk yang terlihat menyeramkan, terkadang memiliki taring dengan lidah menjulur (Hardiati, 2002, hlm. 2-5).

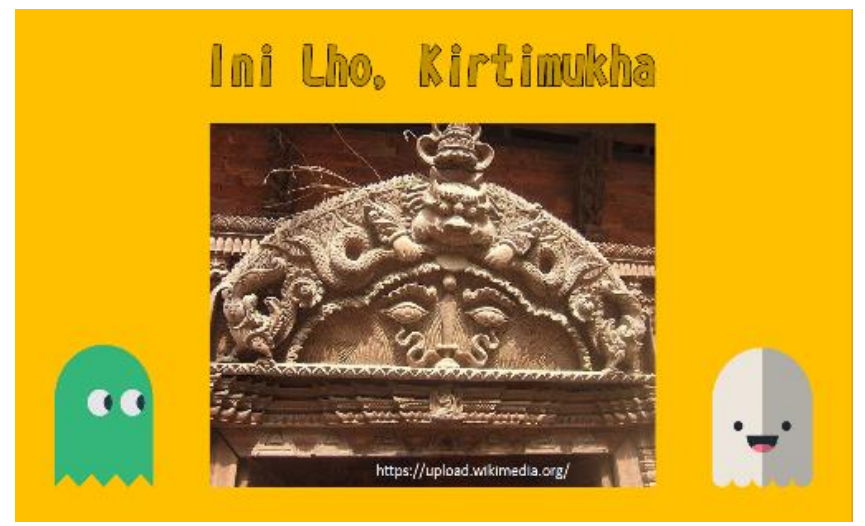

Gambar 6: Penjelasan Arloka Map mengenai Kirttimukha

(Sumber: Tim Arloka)

Penggambaran kala pada candi di Nusantara, khususnya Jawa, berbeda dengan kirttimukha pada kulil di India. Perbedaan tersebut menunjukkan bahwa leluhur Nusantara memiliki cara tersendiri untuk menafsirkan tokoh dalam bangunan suci agama Hindu dan Buddha. Adanya perbedaan ini sangat mungkin terinspirasi dari tokoh atau karakter yang telah dikenal sebelumnya. Bukan tidak mungkin, karakter tersebut memiliki korelasi dengan keberadaan seni topeng dan kala di Nusantara. Kala merupakan salah satu ornamen yang banyak dijumpai di kompleks Candi Sewu (Gambar 7). Tidak hanya sebagai ornamen dekoratif, akan tetapi kala juga dijumpai dalam bentuk dekoratif-konstruktif (Kusen, dkk., 1992, hlm. 64). 


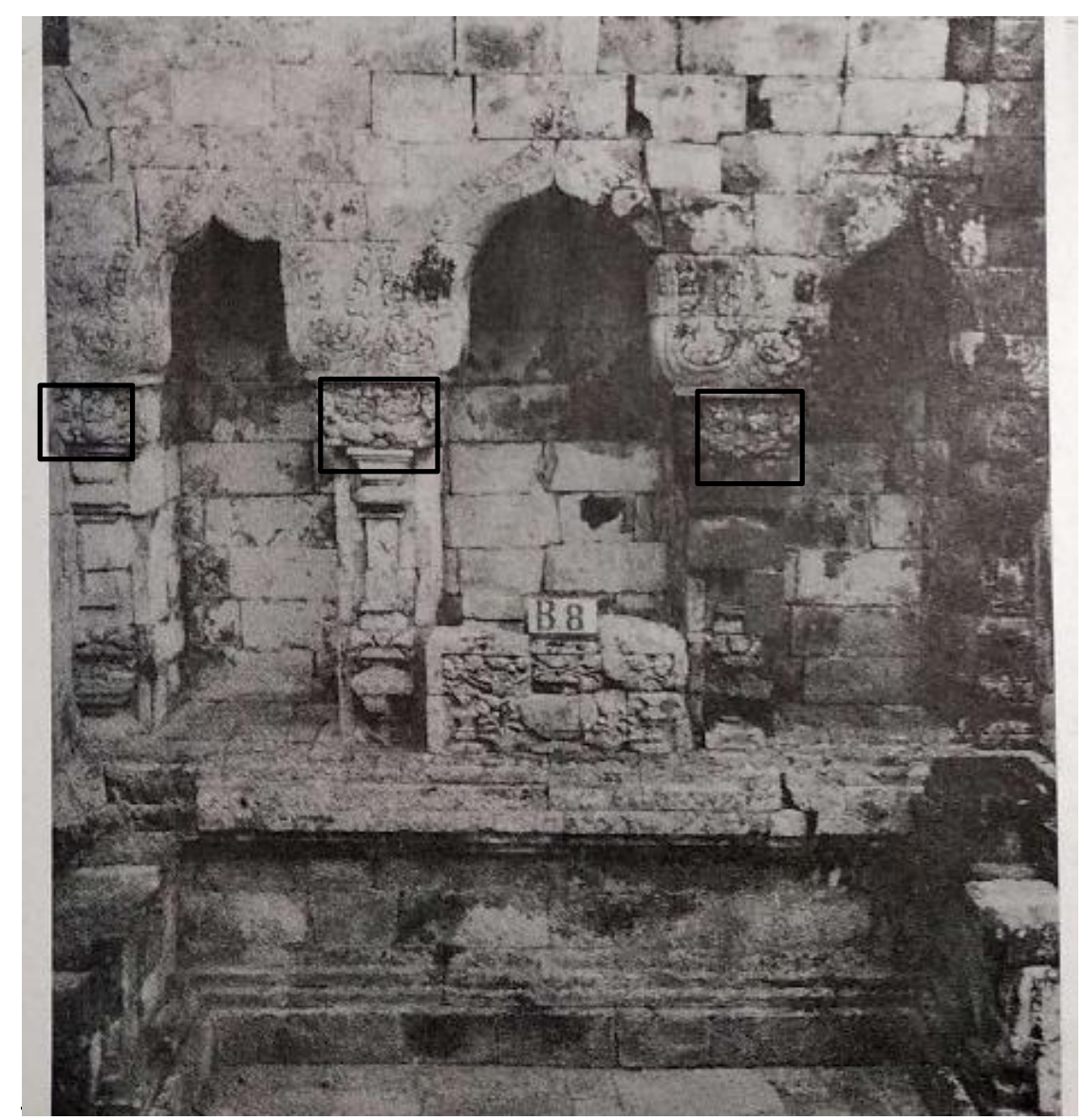

Gambar 7: Ornamen Dekoratif-Konstruktif Kala di Candi Sewu

(Sumber: Kusen, dkk., 1992)

\section{Motif melati di Relief Candi Sewu dan Candi Plaosan}

Di relief Candi Sewu dan Candi Plaosan, wisatawan domestik dapat menemukan melati, puspa bangsa Indonesia. Melati ditetapkan sebagai puspa bangsa berdasarkan Keputusan Presiden Nomor 4 Tahun 1993. Sejak lama, melati telah memiliki hubungan yang erat dengan budaya Jawa. Bahkan, motif melati terpatri dengan baik pada beberapa candi di Jawa, khususnya candi-candi yang dibangun pada masa Mataram Kuno (Gambar 8). Salah satunya pada reruntuhan Candi Sewu.

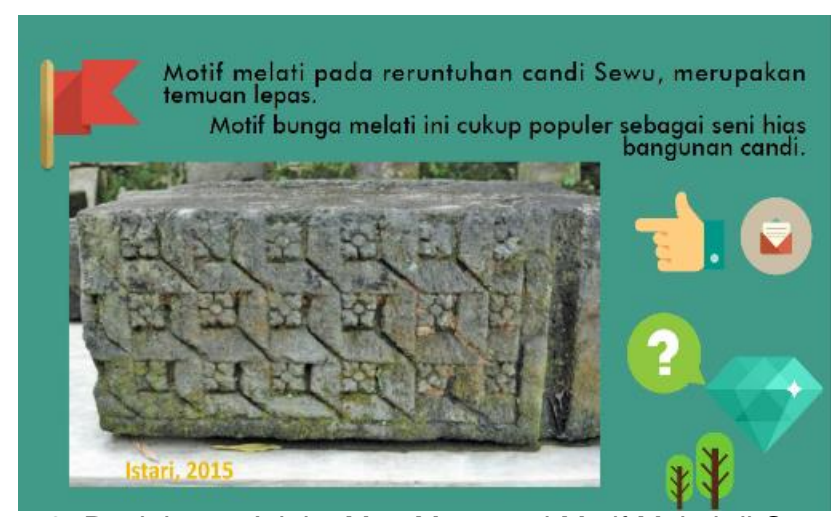

Gambar 8: Penjelasan Arloka Map Mengenai Motif Melati di Candi Sewu (Sumber: Tim Arloka) 
Ditemukannya bunga melati sebagai seni hias di Candi Sewu dan Candi Plaosan menjadi bukti. Jauh sebelum presiden menetapkan melati sebagai puspa bangsa, lebih dari tiga belas abad yang lalu, melati telah menjadi bunga yang penting bagi masyarakat Jawa. Meskipun penggunaan melati secara spesifik di masa Mataram Kuno sulit dilacak melalui catatan prasasti. Namun, keberadaan melati yang dipahatkan pada dinding candi setidaknya menandai posisi penting bunga itu di mata para pemahat relief (Kusen, 1985, hlm. 6). Nilai historis inilah yang sepertinya menjadi pertimbangan pemerintah ketika menetapkan melati sebagai puspa bangsa. Dalam hal ini terdapat pesan: ketika mengambil keputusan, aspek historis perlu diperhatikan agar landasan keputusan menjadi semakin kokoh.

\section{Aspek Teknik Konstruksi di Kawasan Candi Prambanan}

\section{Kearifan lokal konstruksi Candi Prambanan}

Dalam kitab Manasara Silpasastra disebutkan bahwa salah satu aspek terpenting dalam pemilihan lokasi candi adalah harus dibangun dekat dengan sumber mata air (Mundardjito, 2002, hlm. 11). Hal ini dikarenakan adanya kepercayaan kalau sungai adalah tempat suci (Soekmono, 1974, hlm. 329). Arloka Map menjelaskan pada wisatawan domestik, berdasarkan penelitian dan uji geofisik, Candi Prambanan juga mengikuti apa yang dituliskan kitab Manasara Silpasastra. Candi ini dibangun di dekat dua sungai purba. Salah satu sungai bahkan mengalir tepat di bawah kompleks candi. Satu sungai lain mengalir di timurnya. Akibat keberadaan kedua sungai tersebut, diperkirakan dahulunya terdapat genangan air sedalam kurang lebih lima belas meter di bagian selatan kompleks Candi Siwa (Suryolelono dan Rifa'i, 2013, hlm. 28).

Salah satu syarat untuk membangun monumen raksasa adalah daerah tersebut harus benar-benar kering agar tanah yang digunakan kuat menopang bobot monumen. Adanya aliran sungai yang mengalir tepat di bawah Kompleks Candi Prambatan memicu upaya kreatif leluhur Nusantara untuk mengalihkan aliran sungai tersebut menuju sungai di sebelah timurnya. Besar kemungkinan, tanggul pengalih sungai itu dibangun di Halaman III sisi utara. Pekerjaan membangun tanggul diperkirakan beriringan dengan proses penimbunan dasar sungai purba. Material yang digunakan sebagai penimbun antara lain tanah pasir dan bekas galian saluran tanggul (Suryolelono dan Rifa'i, 2013, hlm. 34).

Bentuk Candi Prambanan yang masif memerlukan fondasi kokoh. Leluhur Nusantara mengakali hal tersebut dengan membuat fondasi berupa balok-balok batu yang disusun selapis demi selapis hingga kedalaman yang direncanakan. Fondasi itu kemudian ditimbun dengan tanah. Penggunaan teknik ini memastikan fondasi Candi Prambanan tetap kokoh menopang beban struktur candi hingga berabad-abad sesudahnya (Suryolelono dan Rifa'i, 2013, hlm. 41).

\section{Kearifan lokal konstruksi Candi Plaosan}

Secara geologis, sebenarnya, Candi Plaosan dibangun di wilayah dengan tanah yang kurang kokoh untuk menopang bangunan. Nenek moyang Nusantara kemudian mengadaptasi kondisi itu dengan membuat parit yang mengelilingi Candi Plaosan Lor dan Candi Plaosan Kidul (Gambar 9). Parit ini berfungsi 
sebagai tempat menampung air sehingga kandungan air pada tanah di bagian tengah halaman candi tetap padat dan stabil (Siagian, 2002, hlm. 85).

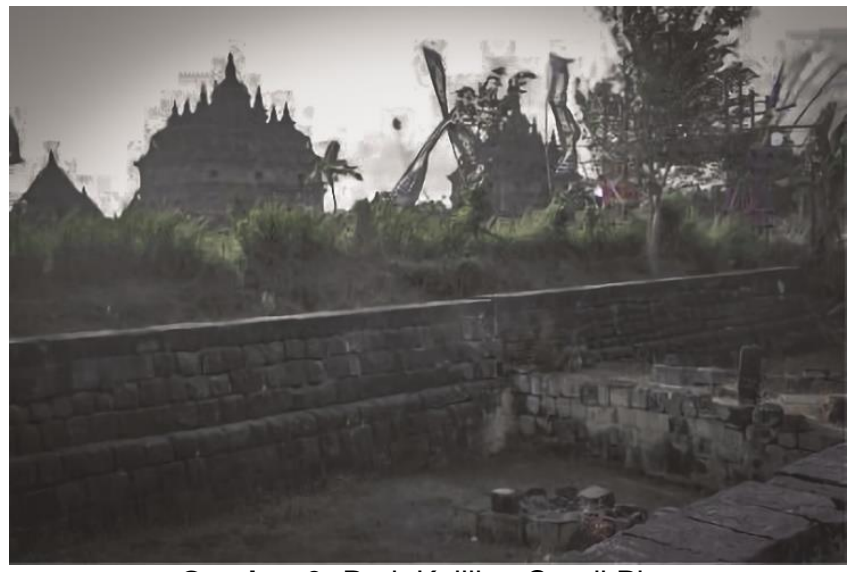

Gambar 9: Parit Keliling Candi Plaosan (Sumber: Tim Arloka)

Bahan yang digunakan untuk membangun Candi Plaosan adalah batu andesit. Penggunaan batu andesit bertujuan untuk memanfatkan sumber daya alam di sekitar lokasi pendirian candi. Candi-candi di Kawasan Prambanan umumnya terbuat dari batu andesit. Batu andesit memiliki massa yang lebih besar daripada batu bata. Menurut Adi Hardiyono6 (2013, hlm. 90-91), dari hasil uji keteknikan didapatkan nilai rata-rata tekan uniaksial (UCS) batu andesit 410,93 kg/cm2 (konstruksi ringan), ketahanan hancur 22,6\% (konstruksi ringan) dan absortio 1,82 (konstruksi berat). Penggunaan batu andesit sebagai bahan baku Candi Plaosan merupakan langkah leluhur Nusantara memanfaatkan sumber daya alam yang tersedia di sekitar lokasi.

\section{Aspek Keletakan Candi di Kawasan Candi Prambanan}

Candi Prambanan dan Candi Sewu merupakan dua bangunan keagamaan masif yang berbeda jarak sekitar dua kilometer. Menariknya, dua bangunan ini dibangun dengan latar agama yang berbeda. Candi Prambanan merupakan bangunan dengan latar keagamaan Hindu-Siwa. Sementara, Candi Sewu adalah bangunan berlatar keagamaan Buddha Mahayana. Berdasarkan tafsir Prasasti Siwagrha, Candi Prambanan mulai dibangun pada pertengahan abad ke-9 Masehi, yakni sekitar tahun 850 Masehi oleh Rakai Panangkaran. Candi Sewu sendiri diperkirakan dibangun pada akhir abad ke-8 Masehi juga di masa Rakai Panangkaran. Perkiraan ini didasarkan pada pembacaan Prasasti Manjursigrha (792 Masehi) dan Prasasti Kelurak (782 Masehi).

Dua bangunan dengan latar keagamaan berbeda pastinya memiliki konsepsi dan ritual yang berbeda pula. Candi Prambanan dan Candi Sewu adalah dua bangunan keagamaan berukuran masif yang dibangun dalam jangka waktu yang tak terpaut lama dan dengan jarak yang relatif dekat. Fenomena di atas secara implisit menandakan toleransi tinggi yang dimiliki masyarakat kerajaan Mataram Kuno. Arloka Map berusaha mengenalkan nilai toleransi yang dimiliki leluhur Nusantara kepada wisatawan masa kini.

${ }^{6}$ Peneliti di Laboratorium Petrologi dan Minerologi, Fakultas Teknik Geologi, Universitas Padjadjaran 


\section{DISKUSI DAN PEMBAHASAN}

Lima puluh wisatawan domestik di Kawasan Candi Prambanan menjadi responden uji efektivitas Arloka Map. Uji dilakukan dengan memberikan pre-test dan post-test kepada responden. Masing-masing tes memiliki sepuluh butir pertanyaan berbentuk pilihan ganda. Pertanyaan-pertanyaan itu disusun sesuai dengan tiga aspek kearifan lokal yang telah dijelaskan di bagian sebelumnya, yaitu aspek seni relief, aspek teknik konstruksi, dan aspek keletakan candi. Selain ketiga aspek tersebut, terdapat beberapa pertanyaan lain yang sifatnya umum dan berupa imbauan.

Pada pre-test, pertanyaan yang sifatnya umum terdapat pada nomor (1); (4); (9); dan (10). Pertanyaan terkait aspek seni relief terdapat pada nomor (3); (6); dan (7). Pertanyaan terkait aspek teknik konstruksi terdapat pada nomor (2) dan (8). Pertanyaan terkait aspek keletakan candi terdapat pada nomor (5).

Pada post-test, pertanyaan yang sifatnya umum terdapat pada nomor (1); (4); (9); dan (10). Pertanyaan terkait aspek seni relief terdapat pada nomor (2); (3); dan (6). Pertanyaan terkait aspek teknik konstruksi terdapat pada nomor (7) dan (8). Pertanyaan terkait aspek keletakan candi terdapat pada nomor (5).

Meskipun beberapa butir pertanyaan pre-test dan post-test berbeda, tetapi pertanyaan di kedua tes telah disusun dalam topik yang sama. Jawaban seluruh pertanyaan dapat responden temukan di konten Arloka Map. Pembedaan butir pertanyaan dimaksudkan untuk melihat seberapa menyeluruh pemahaman wisatawan domestik ketika mereka dihadapkan dengan pertanyaan yang berbeda (tetapi dengan topik yang sama), dari apa yang mereka temui di pre-test.

Pre-test diberikan sebelum instrumen Arloka Map digunakan oleh responden. Tujuannya untuk mengetahui tingkat pemahaman awal responden mengenai Kawasan Candi Prambanan. Baik dari sisi sejarah, arsitektur, dan posisi kawasan dalam perspektif cagar budaya.

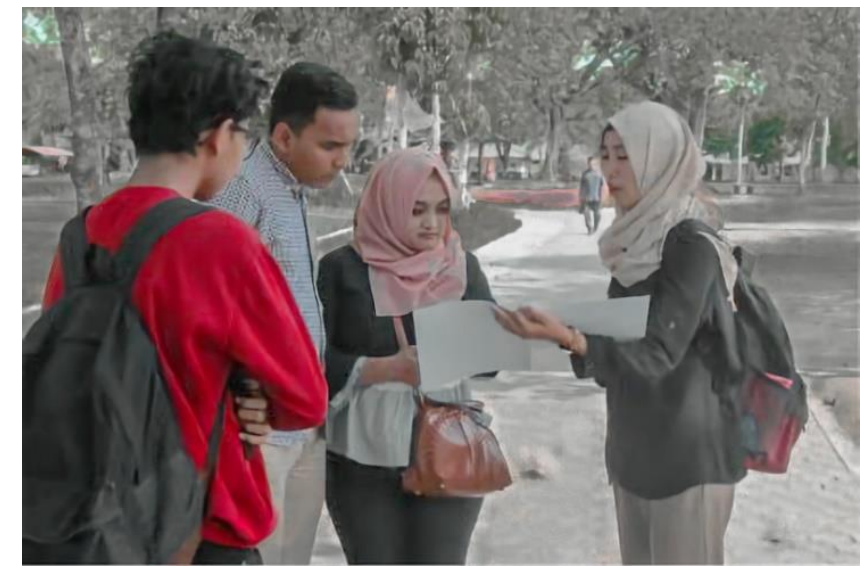

Gambar 10: Pembagian Arloka Map kepada Pengunjung Candi Prambanan (Sumber: Tim Arloka)

Setelah responden mengisi pre-test, Arloka Map dibagikan (Gambar 10). Responden yang telah mendapatkan peta kemudian dipersilahkan untuk berkeliling area candi. Setelah selesai berkeliling, responden diminta mengisi posttest. Berdasarkan hasil analisis menggunakan aplikasi SPSS diperoleh hasil analisis per butir soal. Jumlah skor total pre-test adalah 222 jumlah skor total post-test 
adalah 436. Nilai rata-rata pre-test sebesar 4,44 dan nilai rata-rata post-test 8,72 (Tabel 1).

Tabel 1. Perolehan Nilai Pre-test dan Post-test

\begin{tabular}{lcc}
\hline & Pre-test & Post-test \\
\hline Jumlah Pengunjung & 50 & 50 \\
Jumlah Skor & 222 & 436 \\
Rata-rata & 4,44 & 8,72 \\
& \\
\multicolumn{2}{c}{ Sumber: Tim Arloka, 2017 }
\end{tabular}

Pemahaman wisatawan domestik terhadap ketiga candi di Kawasan Candi Prambanan awalnya masih rendah. Hal tersebut dapat dilihat dari hasil rata-rata nilai pre-test, yakni sebesar 4,44. Nilai yang tidak terlalu tinggi ini mengindikasikan bahwa wisatawan domestik belum memahami sejarah dan nilai-nilai kearifan lokal yang terdapat di Kawasan Candi Prambanan.

Bila dibedah secara lebih mendalam per aspek nilai kearifan lokal, pada pre-test, hanya $67 \%$ responden yang berhasil menjawab dengan benar pertanyaan terkait aspek seni relief. Pertanyaan terkait aspek teknik konstruksi berhasil dijawab dengan benar oleh $42 \%$ responden. Sementara, pertanyaan terkait aspek keletakan candi berhasil dijawab dengan benar oleh $68 \%$ responden.

Setelah responden memakai Arloka Map, terjadi peningkatan nilai keseluruhan dengan nilai rata-rata post-test sebesar 8,72. Fenomena tersebut menunjukkan adanya peningkatan pemahaman responden terhadap nilai-nilai kearifan lokal Kawasan Candi Prambanan. Pada tahap ini, secara rinci, 87\% responden berhasil menjawab dengan benar pertanyaan terkait aspek seni relief. Pertanyaan terkait aspek teknik konstruksi berhasil dijawab dengan benar oleh $82 \%$ responden. Sementara, pertanyaan terkait aspek keletakan candi berhasil dijawab dengan benar oleh $90 \%$ responden.

Penggunaan Arloka Map ternyata mampu membantu menjelaskan informasi candi dan mengomunikasikan nilai kearifan lokal Kawasan Candi Prambanan kepada wisatawan domestik yang tengah berkunjung. Hal ini diperoleh dari hasil analisis SPSS yang menunjukkan adanya peningkatan nilai rata-rata pengunjung sebanyak 4,28 poin.

\section{KESIMPULAN}

Pemahaman masyarakat yang rendah terhadap nilai-nilai kearifan lokal yang terdapat pada Kawasan Candi Prambanan menunjukkan gejala kesenjangan antara arkeologi dengan masyarakat. Dari perspektif Arkeologi Publik, Arloka Map dapat menjadi jembatan kecil untuk semakin mendekatkan ranah arkeologi kepada masyarakat Indonesia. Mengingat, wisatawan domestik memberikan respons positif setelah pembagian Arloka Map. Penggunaan Arloka Map ternyata mampu membantu menjelaskan informasi candi dan mengomunikasikan nilai kearifan lokal Kawasan Candi Prambanan kepada wisatawan domestik yang tengah berkunjung. Hal ini dibuktikan dengan meningkatnya nilai rata-rata responden sebanyak 4,28 poin. 
Setelah Arloka Map dibagikan, tingkat pemahaman responden yang diwakili oleh hasil pre-test dan post-test, mengalami peningkatan pada setiap aspek kearifan lokal. Terkait aspek seni relief, terjadi peningkatan sebanyak $20 \%$. Pada aspek konstruksi, pemahaman responden meningkat hingga 40\%. Sementara, terkait aspek keletakan candi terjadi peningkatan pemahaman sebanyak $32 \%$.

Hasil penelitian yang dipaparkan merupakan tahap awal yang masih membutuhkan banyak evaluasi dan pengembangan. Penulis menyadari bahwa untuk memperoleh hasil yang lebih matang, konsep Arloka Map yang penulis tawarkan harus melewati beberapa kali pengujian dan penyesuaian. Penentuan konten informasi yang akan disampaikan juga perlu diperhatikan dengan cermat. Dengan demikian, tujuan penyampaian informasi dan muatan kearifan lokal pada Kawasan Candi Prambanan sebagai bagian dari upaya arkeologi publik dapat terpenuhi. Harapannya, kelak masyarakat dapat benar-benar mengambil peran utama dalam pemanfaatan dan pelestarian cagar budaya di Indonesia, sebagaimana tujuan dan paradigma perspektif Arkeologi Publik modern.

\section{UCAPAN TERIMA KASIH}

Ucapan terima kasih sebesar-besarnya penulis berikan kepada Dwi Pradnyawan, S.S., M.A., selaku dosen pembimbing pada saat penelitian. Fahmi Febrian Adiyasa, selaku tim dokumentasi. Muammar Nandika, selaku tim yang membantu pengolahan Arloka Map. Balai Pelestarian Cagar Budaya Daerah Istimewa Yogyakarta, Balai Pelestarian Cagar Budaya Jawa Tengah, dan PT. Taman Wisata Candi Borobudur, Prambanan, dan Ratu Boko, yang telah memberikan izin penelitian. 


\section{DAFTAR PUSTAKA}

Amril, F. (2016). Cyber Arkeologi Dalam Komunikasi Arkeologi kepada Publik sebagai Sarana Pelestarian Cagar Budaya. Jurnal Konservasi Cagar Budaya Borobudur, 10(2), 3-9.

Ayatrohaedi. (1979). Dialektologi: Sebuah Pengantar. Jakarta: Pusat Pembinaan dan Pengembangan Bahasa.

Badan Pusat Statistik Kabupaten Klaten. (2018). Kabupaten Klaten dalam Angka 2018.

Badan Pusat Statistik Kabupaten Sleman. (2018). Kabupaten Sleman dalam Angka 2018.

Gillet, S., Schmitz, P., \& Mitas, O. (2013). The Snap-Happy Tourist: The Effects of Photographing Behavior on Tourists' Happiness. Journal of Hospitality $\mathcal{E}$ Tourism Research, 40(1), 37-57.

Grima, R. (2009). A Reply to What is Public Archaeology?. Present Pasts, 1, 53-54.

Haldrup, M. \& Larsen, J. (2003). The Family Gaze. Tourist Studies, 3(1) 23-46.

Hardiati, E. (2002). Aspek Arsitektural dan Aspek Simbolik Bangunan Candi. Dalam R. Siagian, Candi sebagai Warisan Seni dan Budaya Indonesia (h. 1-4). Yogyakarta: Yayasan Kencana Cempaka.

Hardiyono, A. (2013). Karakteristik Batuan Beku Andesitik \& Breksi Vulkanik dan Kemungkinan Penggunaan sebagai Bahan Bangunan Daerah Ukir Sari, Kec. Bojonegara, Kab. Serang, Jawa Barat. Jurnal Bulletin of Scientific Contribution, 11(2), 89-95.

Hastuti, S.D.H. (2017). Pengaruh Perilaku Berfoto di Obyek Wisata Terhadap Kebahagiaan Wisatawan. Jurnal Media Wisata, 15(2), 540-554.

Holt, C. (2000). Melacak Jejak Perkembangan Seni di Indonesia. Bandung: Arti Line.

Kusen. (1985). Kreativitas dan Kemandirian Seniman Jawa dalam Pengaruh Budaya Asing: Studi Kasus tentang Gaya Seni Relief Candi di Jawa antara Abad IX-XVI Masehi. Jakarta: Departemen Pendidikan dan Kebudayaan.

Kusen, Kusumajaya, I.M., Gutomo, Hidayat, R.C., Murdijono, Sudarno, Suhardi. (1992). Candi Sewu Sejarah dan Pemugarannya. Klaten: Suaka Peninggalan Sejarah dan Purbakala Jawa Tengah.

Lestari, W. (2000). Peran Lokal Genius Dalam Kesenian Lokal. Harmonia: Jurnal Pengetahuan dan Pemikiran Seni, 1(2), 29-37.

Matsuda, A. (2004). The Concept of 'the Public' and the Aims of Public Archaeology. Papers from the Institute of Archaeology, 15, 66-76. 
Mundarjito. (2002). Pertimbangan Ekologis: Penempatan Situs Masa Hindu-Buda di Daerah Yogyakarta. Jakarta: Wedatama Widya Sastra dan École Française d'Extrême-Orient.

Nawawi, H. (2003). Metode Penelitian Bidang Sosial. Yogyakarta: Gadjah Mada University Press.

Raharjana, D.T., Damanik, J., \& Setyastuti, A. (2016). Riset-Aksi Perancangan dan Pelaksanaan Program Pemberdayaan Masyarakat Kawasan Cagar Budaya Prambanan. Jurnal Widya Prabha, 5(5), 3-23.

Restiyadi, A. (2006). Analisis Sintaktik, Semantik, dan Kreativitas Seniman Jawa dalam Pembingkaian Tanda Visual Naratifpada Relief Cerita Krsna di Candi Prambanan (Sebuah Pendekatan Semiotika Desain) (Skripsi). Yogyakarta: Fakultas Ilmu Budaya, UGM.

Sagala, P. L. (2017). Motivasi Wisatawan Berkunjung ke Daerah Tujuan Wisata Danau Toba Sumatera Utara. JOM FISIP , 4(1), 1-15.

Sedyawati, E. (1994). Pengarcaan Ganesa Masa Kadiri dan Sinhasari Sebuah Tinjauan Sejarah Kesenian. Jakarta: Lembaga Ilmu Pengetahuan Indonesia

Sedyawati, E. (2006). Budaya Indonesia: Kajian Arkeologi, Seni, dan Sejarah. Jakarta: Raja Grafindo.

Siagian, R. (2002). Candi sebagai Warisan Seni dan Budaya Indonesia. Yogyakarta: Yayasan Cempaka Kencana.

Suryolelono, K.B. \& Rifa'i, A. (2013). Menguak Misteri Pembangunan Candi Prambanan. Dalam Sektiadi (Ed), Candi Prambanan: Perspektif Multidisiplin dan Multistakeholder (h. 19-41). Yogyakarta: Balai Pelestarian Cagar Budaya Yogyakarta.

Soekmono. (1974). Candi, Fungsi, dan Pengertiannya (Disertasi). Depok: Fakultas Ilmu Budaya, Universitas Indonesia.

Tanudirjo, D.A. (2013). Arkeologi dan Masyarakat. Dalam S. Atmosudiro, \& T. Prasodjo (Eds.), Arkeologi dan Publik (h. 3-16). Yogyakarta: Kepel Press.

Wibowo, A., dkk. (2006). Topeng dan Lengger. Yogyakarta: Fakultas Ilmu Budaya, UGM.

Yadav, J.S. (2002). Pengaruh Budaya India pada Candi di Indonesia. Dalam R. Siagian, Candi sebagai Warisan Seni dan Budaya Indonesia (h. 5-14). Yogyakarta: Yayasan Kencana Cempaka.

Yusnitha, T. S. (2017). Faktor-Faktor yang Mempengaruhi Kunjungan Wisatawan ke Candi Prambanan (Skripsi). Solo: Fakultas Geografi, Universitas Muhammadiyah Surakarta. 


\section{LAMPIRAN}

\section{SOAL PRETEST}

1. Candi Prambanan menupakan candi peninggalan dari masa Kerajaan...
a. Majapahit
c. Mataram Kuno
b. Sriwijaya
d. Kediri

2. Nenek moyang kita pada masa Hindu Budha dalam mendirikan candi memerhatikan lokasi sumber daya alam berupa batuan. Hal tersebut menunjukkan contoh adaptasi dari aspek...
a. Astronomi
c. Religi
b. Linghangan
d. Keamanan

3. Relief merupakan salah satu seni pahat yang terdapat di candi. Relief khas yang berhubungan dengan kegiatan kesenian di Candi Prambanan adalah relief ...
a. Pertunjukan musik
c. Kuda Lumping
b. Melukis
d. Warok

4. Legenda yang terdapat di Candi Prambanan adalah Roro Joggrang. Arca di Prambanan yang dipercaya sebagai perwujudan Roro Jonggrang adalah arca..
a. Dewi Uma
c. Ganesha
b. Durga
d. Shinta

5. Contoh nilai karakter bangsa Indonesia yang dapat dipelajari dari letak Candi Prambanan dan Candi Sewu yang gangat dekat adalah.
a. Toleransi beragama
c. Bertanggungjawab
b. Jujur
d. Kerja keras

6. Penggambaran tokoh yang memiliki karakter geram seperti raksasa yang terdapat di atas pintu masuk candi adalah...-
a. Agastya
c. Kala
b. Ganeshs
d. Gupala

7. Salah gatu relief istimewa berupa flora dari Candi Sewu dan tidak ditenukan di candi lain di Kawasan Prambanan adalah....
a. Padma
c. Melati
b. Kenanga
d. Anggrek

8. Contoh kearifan lokal leluhur bangsa Indonesia yang ada di Candi Plaosan, yang merupakan upaya adaptasi dengan linghungan adalah..
a. Mandapa
c. Gupala
b. Stupa
d. Parit keliling

9. Bangunan utama di Candi Plaosan dikelilingi oleh bangunan pendamping yang disebut.
a. Pagar keliling
d. Parit keliling
b. Candi perwara dan stupa perwarae. Mandapa

10. Ketika berkunjung ke candi hal yang dapat dilakukan untuk ikut gerta melestarikan candi adalah.
a. Tidak memanjat batu candi
d. Menggambar di batu candi
b. Membuang sampah gembarangan e. Memindahkan batu candi

Gambar 1.1: Soal Pre-test

(Sumber: Tim Arloka) 
SOAL POSTTEST

1. Candi Prambanan merupakan candi yang memiliki latar keagamaan..
a. Hindu
c. Islam
b. Budha
d. Kristen

2. Cerita yang dipahatakan di didinding Candi Prambanan adalah....
a. Ramayanan dan Krisna
c. Tantrayana
b. Jataka
d. Fabel

3. Relief merupakan salah satu seni pahat yang terdapat di candi. Relief khas yang berhubungan dengan kegiatan kesenian di Candi Prambanan adalah relief ....
a. Pertunjukan musik
c. Kuda Lumping
b. Melukis
d. Warok

4. Legenda yang terdapat di Candi Prambanan adalah Roro Joggrang. Arca di Prambanan yang dipercaya sebagai perwujudan Roro Jonggrang adalah arca..
a. Dewi Uma
c. Ganesha
b. Durga
d. Shinta

5. Contoh nilai karakter bangsa Indonesia yang dapat dipelajari dari letak Candi Prambanan dan Candi Sewu yang gangat dekat adalah.
a. Toleransi beragama
c. Bertanggungjawab
b. Jujur
d. Kerja keras

6. Arca yang berada di depan halaman masuk Candi Sewu berfungsi sebagai penjaga gerbang candi adalah arca.
a. Agastya
c. Kala
b. Ganesha
d. Gupala

7. Ciri utama puncak candi yang dimiliki Candi Budha seperti Candi Sewu adalah....
a. Ratma
c. Lingga
b. Arca
d. Stupa

8. Contoh kearifan lokal leluhur bangsa Indonesia yang ada di Candi Plaosan, yang merupakan upaya adaptasi dengan lingkungan adalah
a. Mandapa
b. Stupa
c. Gupala
d. Parit keliling

9. Bangunan utama di Candi Plaosan dikelilingi oleh bangunan pendamping yang disebut.
a. Pagar keliling
d. Parit keliling
b. Candi perwara dan stupa perwarae. Mandapa

10. Ketika berkunjung ke candi hal yang dapat dilakukan untuk ikut serta melestarikan candi adalah.
a. Tidak memanjat batu candi
d. Menggambar di batu candi
b. Membuang gampah sembarangan e. Memindahkan batu candi

Gambar 1.2: Soal Post-test

(Sumber: Tim Arloka) 


\begin{tabular}{|c|c|c|c|c|c|c|c|c|c|c|c|c|}
\hline No & Nama & Soal 1 & Soal 2 & Soal 3 & Soal 4 & Soal 5 & Soal 6 & Soal 7 & Soal 8 & Soal 9 & Soal 10 & Skor \\
\hline 1 & Eko W & 0 & 1 & 0 & 0 & 1 & 0 & 0 & 0 & 0 & 1 & 3 \\
\hline 2 & Farida Ema N.F. & 1 & 1 & 0 & 1 & 1 & 0 & 1 & 0 & 0 & 0 & 5 \\
\hline 3 & Marlina Dwi Saputri & 1 & 1 & 0 & 1 & 1 & 1 & 0 & 0 & 1 & 0 & 6 \\
\hline 4 & Septyaningrum & 0 & 0 & 0 & 0 & 1 & 0 & 0 & 0 & 0 & 1 & 2 \\
\hline 5 & Fitri Lestari & 1 & 0 & 0 & 0 & 1 & 0 & 0 & 1 & 1 & 1 & 5 \\
\hline 6 & Nur Budiman & 1 & 1 & 1 & 0 & 0 & 0 & 0 & 0 & 0 & 1 & 4 \\
\hline 7 & Inayatul Khasanah & 1 & 1 & 0 & 1 & 1 & 0 & 0 & 1 & 1 & 1 & 7 \\
\hline 8 & Dwi Puspo & 1 & 1 & 1 & 1 & 0 & 1 & 0 & 0 & 1 & 1 & 7 \\
\hline 9 & Amin & 1 & 1 & 0 & 0 & 0 & 0 & 0 & 0 & 1 & 0 & 3 \\
\hline 10 & Kosim & 1 & 0 & 1 & 0 & 0 & 0 & 0 & 0 & 1 & 1 & 4 \\
\hline 11 & Kus Haryanti & 1 & 0 & 1 & 0 & 0 & 0 & 1 & 1 & 0 & 0 & 4 \\
\hline 12 & Wawan & 1 & 1 & 0 & 1 & 1 & 1 & 0 & 1 & 1 & 1 & 8 \\
\hline 13 & Retha & 0 & 1 & 0 & 0 & 1 & 0 & 0 & 1 & 1 & 1 & 5 \\
\hline 14 & Wiji & 0 & 1 & 0 & 1 & 0 & 0 & 0 & 1 & 0 & 1 & 4 \\
\hline 15 & Siska Anggun & 1 & 0 & 0 & 0 & 1 & 0 & 1 & 0 & 0 & 1 & 4 \\
\hline 16 & Treivi Anggi Nugroho & 1 & 1 & 1 & 0 & 0 & 0 & 0 & 1 & 0 & 0 & 4 \\
\hline 17 & Novita Sari & 1 & 0 & 0 & 1 & 1 & 1 & 1 & 0 & 0 & 0 & 5 \\
\hline 18 & Yusuf & 1 & 0 & 1 & 0 & 0 & 0 & 1 & 1 & 0 & 0 & 4 \\
\hline 19 & Dessy & 0 & 0 & 0 & 0 & 0 & 0 & 0 & 0 & 1 & 1 & 2 \\
\hline 20 & Restu Wandiro & 0 & 0 & 0 & 0 & 1 & 0 & 0 & 0 & 1 & 1 & 3 \\
\hline 21 & F. Supriyadi & 1 & 1 & 0 & 1 & 1 & 1 & 0 & 1 & 1 & 1 & 8 \\
\hline 22 & Adil Santoso & 0 & 1 & 0 & 1 & 1 & 1 & 0 & 0 & 0 & 0 & 4 \\
\hline 23 & Syamsul Arifin & 0 & 1 & 0 & 0 & 0 & 0 & 0 & 0 & 0 & 0 & 1 \\
\hline 24 & Wahyu Pratama Aji & 0 & 1 & 0 & 0 & 0 & 0 & 0 & 0 & 0 & 0 & 1 \\
\hline 25 & Erwin & 1 & 0 & 0 & 0 & 0 & 1 & 0 & 0 & 0 & 0 & 2 \\
\hline 26 & Bandya & 0 & 0 & 0 & 1 & 1 & 1 & 0 & 0 & 0 & 1 & 4 \\
\hline
\end{tabular}

Gambar 1.3: Lampiran Nilai Pre-test (A)

(Sumber: Tim Arloka)

\begin{tabular}{|r|l|r|r|r|r|r|r|r|r|r|r|r|}
\hline 27 & Suryanto & 1 & 1 & 0 & 1 & 0 & 0 & 1 & 0 & 1 & 1 & 6 \\
\hline 28 & Lauren Rumere & 0 & 0 & 0 & 1 & 1 & 0 & 0 & 0 & 1 & 1 & 4 \\
\hline 29 & Okif & 1 & 0 & 1 & 0 & 1 & 0 & 0 & 0 & 1 & 1 & 5 \\
\hline 30 & Agus & 1 & 1 & 0 & 0 & 1 & 0 & 0 & 0 & 1 & 1 & 5 \\
\hline 31 & Atsa & 1 & 0 & 0 & 1 & 1 & 0 & 0 & 0 & 1 & 1 & 5 \\
\hline 32 & Doni P. & 0 & 1 & 1 & 1 & 1 & 0 & 0 & 0 & 0 & 1 & 5 \\
\hline 33 & Rahman & 0 & 1 & 1 & 0 & 1 & 0 & 0 & 0 & 1 & 1 & 5 \\
\hline 34 & Masyhuri & 0 & 0 & 1 & 1 & 1 & 1 & 0 & 0 & 1 & 1 & 6 \\
\hline 35 & Arief Bahari & 0 & 0 & 0 & 0 & 1 & 1 & 1 & 0 & 0 & 1 & 4 \\
\hline 36 & Arum Rohmati Ummah & 0 & 1 & 1 & 0 & 1 & 0 & 0 & 0 & 0 & 1 & 4 \\
\hline 37 & Elisabeth Hertami & 1 & 1 & 1 & 1 & 1 & 1 & 0 & 1 & 1 & 1 & 9 \\
\hline 38 & Eko Supianto & 1 & 1 & 1 & 0 & 0 & 1 & 0 & 1 & 1 & 1 & 7 \\
\hline 39 & Narko & 1 & 1 & 1 & 0 & 0 & 0 & 0 & 1 & 1 & 1 & 6 \\
\hline 40 & Sofia & 1 & 1 & 0 & 0 & 1 & 1 & 0 & 1 & 1 & 1 & 7 \\
\hline 41 & Nanang Prasetyo & 1 & 1 & 1 & 0 & 1 & 0 & 0 & 1 & 1 & 1 & 7 \\
\hline 42 & M. Luthfi & 0 & 0 & 0 & 0 & 1 & 0 & 0 & 0 & 0 & 0 & 1 \\
\hline 43 & Toro & 1 & 0 & 0 & 1 & 1 & 0 & 0 & 1 & 1 & 0 & 5 \\
\hline 44 & Iga Djaman & 0 & 1 & 0 & 0 & 1 & 0 & 0 & 0 & 0 & 0 & 2 \\
\hline 45 & Adinda Putri H. & 0 & 0 & 0 & 0 & 1 & 0 & 0 & 0 & 0 & 1 & 2 \\
\hline 46 & Santhi & 0 & 0 & 0 & 0 & 1 & 1 & 0 & 0 & 1 & 1 & 4 \\
\hline 47 & Delvi & 0 & 0 & 1 & 0 & 1 & 0 & 0 & 0 & 1 & 1 & 4 \\
\hline 48 & Rifka & 0 & 0 & 0 & 0 & 0 & 0 & 0 & 1 & 1 & 1 & 3 \\
\hline 49 & Fakhry Rizky & 0 & 0 & 1 & 0 & 1 & 0 & 0 & 0 & 0 & 1 & 3 \\
\hline 50 & Maryam & 1 & 0 & 0 & 0 & 1 & 0 & 0 & 0 & 1 & 1 & 4 \\
\hline
\end{tabular}

Gambar 1.4: Lampiran Nilai Pre-test (B) (Sumber: Tim Arloka) 


\begin{tabular}{|c|c|c|c|c|c|c|c|c|c|c|c|c|}
\hline \multicolumn{13}{|c|}{ 10san } \\
\hline No & Nama & 1 & 2 & 3 & 4 & 5 & 6 & 7 & 8 & 9 & 10 & \\
\hline 1 & Eko W & 1 & 0 & 1 & 1 & 1 & 0 & 1 & 1 & 1 & 1 & 8 \\
\hline 2 & Farida Ema N.F. & 1 & 1 & 0 & 1 & 1 & 1 & 1 & 1 & 1 & 1 & 9 \\
\hline 3 & Marlina Dwi S. & 0 & 1 & 0 & 1 & 1 & 1 & 1 & 1 & 1 & 1 & 8 \\
\hline 4 & Septyaningrum & 1 & 1 & 1 & 1 & 1 & 1 & 1 & 1 & 1 & 1 & 10 \\
\hline 5 & Fitri Lestari & 1 & 1 & 0 & 1 & 1 & 1 & 1 & 1 & 0 & 1 & 8 \\
\hline 6 & Nur Budiman & 1 & 0 & 1 & 1 & 0 & 1 & 1 & 0 & 0 & 1 & 6 \\
\hline 7 & Inayatul Khasanah & 1 & 1 & 1 & 1 & 1 & 1 & 1 & 1 & 1 & 1 & 10 \\
\hline 8 & Dwi Puspo & 1 & 1 & 1 & 1 & 1 & 0 & 1 & 1 & 0 & 1 & 8 \\
\hline 9 & Amin & 1 & 1 & 1 & 1 & 1 & 1 & 1 & 1 & 1 & 1 & 10 \\
\hline 10 & Kosim & 1 & 1 & 1 & 0 & 0 & 0 & 0 & 0 & 1 & 1 & 5 \\
\hline 11 & Kus Haryanti & 1 & 0 & 1 & 0 & 0 & 0 & 1 & 1 & 0 & 0 & 4 \\
\hline 12 & Wawan & 1 & 1 & 0 & 1 & 1 & 1 & 0 & 1 & 1 & 1 & 8 \\
\hline 13 & Retha & 1 & 1 & 1 & 1 & 1 & 1 & 1 & 1 & 1 & 1 & 10 \\
\hline 14 & Wiji & 1 & 1 & 1 & 1 & 1 & 1 & 1 & 1 & 1 & 1 & 10 \\
\hline 15 & Siska Anggun & 1 & 1 & 1 & 1 & 1 & 1 & 1 & 1 & 1 & 1 & 10 \\
\hline 16 & Treivi Anggi N. & 1 & 1 & 1 & 1 & 1 & 0 & 0 & 0 & 1 & 1 & 7 \\
\hline 17 & Novita Sari & 1 & 1 & 1 & 0 & 1 & 1 & 1 & 1 & 1 & 1 & 9 \\
\hline 18 & Yusuf & 1 & 1 & 1 & 1 & 1 & 0 & 1 & 1 & 1 & 1 & 9 \\
\hline 19 & Dessy & 1 & 1 & 1 & 1 & 1 & 1 & 1 & 1 & 1 & 1 & 10 \\
\hline 20 & Restu Wandiro $\mathrm{S}$. & 1 & 1 & 1 & 1 & 1 & 1 & 1 & 1 & 1 & 1 & 10 \\
\hline 21 & F. Supriyadi & 1 & 1 & 1 & 1 & 1 & 1 & 1 & 1 & 1 & 1 & 10 \\
\hline 22 & Adil Santosa & 1 & 1 & 1 & 1 & 1 & 1 & 1 & 1 & 1 & 1 & 10 \\
\hline 23 & Syamsul Arifin & 1 & 1 & 1 & 1 & 1 & 1 & 1 & 1 & 1 & 0 & 9 \\
\hline 24 & Wahyu Pratama Aji & 1 & 1 & 1 & 1 & 1 & 1 & 1 & 1 & 1 & 0 & 9 \\
\hline 25 & Erwin & 1 & 1 & 1 & 1 & 1 & 1 & 1 & 0 & 0 & 1 & 8 \\
\hline 26 & Bandya & 1 & 1 & 1 & 1 & 1 & 1 & 1 & 1 & 1 & 1 & 10 \\
\hline
\end{tabular}

Gambar 1.5: Lampiran Nilai Soal Post-test (A)

(Sumber: Tim Arloka)

\begin{tabular}{|r|l|r|r|r|r|r|r|r|r|r|r|r|}
\hline 27 & 1 & 1 & 1 & 1 & 1 & 1 & 1 & 1 & 1 & 1 & 10 \\
\hline 28 & Laurens Rumere & 1 & 1 & 0 & 1 & 1 & 0 & 0 & 0 & 0 & 1 & 5 \\
\hline 29 & Okif & 1 & 1 & 1 & 1 & 1 & 1 & 1 & 1 & 1 & 1 & 10 \\
\hline 30 & Agus & 1 & 1 & 1 & 1 & 1 & 1 & 0 & 1 & 1 & 1 & 9 \\
\hline 31 & Atsa & 1 & 1 & 1 & 1 & 1 & 1 & 1 & 1 & 1 & 1 & 10 \\
\hline 32 & Doni P & 1 & 1 & 1 & 1 & 1 & 1 & 1 & 1 & 1 & 1 & 10 \\
\hline 33 & Rahman & 1 & 1 & 1 & 1 & 1 & 1 & 1 & 1 & 1 & 1 & 10 \\
\hline 34 & Masyhuri & 1 & 1 & 1 & 0 & 0 & 1 & 1 & 1 & 1 & 1 & 8 \\
\hline 35 & Arief Bahari & 1 & 1 & 1 & 0 & 1 & 0 & 1 & 1 & 1 & 1 & 8 \\
\hline 36 & Arum Rohmati U. & 1 & 1 & 1 & 1 & 1 & 1 & 1 & 1 & 1 & 1 & 10 \\
\hline 37 & Elisabeth Hertami & 1 & 1 & 1 & 1 & 1 & 1 & 1 & 1 & 1 & 1 & 10 \\
\hline 38 & Eko Supianto & 1 & 1 & 1 & 1 & 1 & 1 & 1 & 1 & 1 & 1 & 10 \\
\hline 39 & Narko & 1 & 1 & 1 & 1 & 1 & 1 & 1 & 1 & 1 & 1 & 10 \\
\hline 40 & Sofia & 1 & 1 & 1 & 1 & 1 & 1 & 1 & 1 & 1 & 1 & 10 \\
\hline 41 & Nanag Prasetyo & 1 & 1 & 1 & 1 & 1 & 1 & 1 & 0 & 1 & 1 & 9 \\
\hline 42 & M. Luthfi & 0 & 1 & 0 & 0 & 1 & 0 & 0 & 0 & 0 & 1 & 3 \\
\hline 43 & Toro & 1 & 1 & 1 & 1 & 1 & 1 & 1 & 1 & 0 & 1 & 9 \\
\hline 44 & Iga Djaman & 1 & 1 & 1 & 1 & 1 & 1 & 0 & 1 & 1 & 1 & 9 \\
\hline 45 & Adinda Putri H. & 1 & 1 & 1 & 1 & 1 & 1 & 0 & 1 & 1 & 1 & 8 \\
\hline 46 & Santhi & 1 & 1 & 1 & 1 & 1 & 1 & 1 & 1 & 1 & 1 & 10 \\
\hline 47 & Delvi & 1 & 1 & 1 & 1 & 1 & 1 & 1 & 1 & 1 & 1 & 10 \\
\hline 48 & Rifka & 1 & 1 & 1 & 1 & 1 & 1 & 0 & 1 & 0 & 1 & 8 \\
\hline 49 & Fakhry Rizky & 1 & 0 & 1 & 0 & 0 & 0 & 0 & 1 & 1 & 5 \\
\hline 50 & Maryam & 1 & 1 & 1 & 1 & & & & \\
\hline
\end{tabular}

Gambar 1.6: Lampiran Nilai Soal Post-test (B)

(Sumber: Tim Arloka) 